\title{
Detecting the Proximities of Mines to Settlements in Turkey through the CORINE Database
}

\author{
İlgi ATAY KAYA \\ Dokuz Eylül University, Faculty of Architecture, İzmir, Turkey \\ Geliş Tarihi (Received): 23.03.2021, Kabul Tarihi (Accepted): 25.04.2021 \\ $\square$ Sorumlu Yazar (Corresponding author): ilgi.kaya@deu.edu.tr \\ (C) +902323018374 㔯 +902324532986
}

\begin{abstract}
The proximity of mineral extraction sites to settlements is a conflicting issue for urban studies. This study aims at exploring the change in the proximity of mines to settlements in Turkey between the years 2012 and 2018 and determining the cities which continue to be near mineral extraction sites. For this aim, analysis tools of Geographic Information Systems (GIS) are used with the mineral extraction sites and urban settlements layers of the Coordination of Information on the Environment (CORINE) land cover data of Turkey for these years. The findings of this study showed that the area of mines adjacent to settlements is increased from nearly 19905 hectares to nearly 21305 hectares and the area of mineral extraction sites within 1 and 500 meters to the nearest settlements is increased from nearly 16421 hectares to nearly 19967 hectares from 2012 to 2018.
\end{abstract}

Keywords: CORINE land cover, geographic information systems, mines, proximity, settlements

\section{CORINE Veritabanı Üzerinden Türkiye'deki Madenlerin Yerleşimlere Yakınlıklarının Tespiti}

ÖZ

Maden çıkarım sahalarının yerleşim yerlerine yakınlığı kentsel çalışmalar için çelişkili bir konudur. Bu çalışma, 20122018 yılları arasında Türkiye'deki madenlerin yerleşim yerlerine yakınlığındaki değişimi araştırmayı ve maden çıkarım sahalarının yakınında olmaya devam eden şehirleri belirlemeyi amaçlamaktadır. Bu amaçla Çevresel Bilginin Koordinasyonu (CORINE) arazi örtüsü verilerinden Türkiye'nin bu yıllara ait maden çıkarım sahaları ve kentsel yerleşim katmanları ile Coğrafi Bilgi Sistemleri (CBS) analiz araçları kullanılmaktadır. Bu çalışmanın bulguları, 2012'den 2018'e kadar yerleşim yerlerine bitişik maden alanlarının yaklaşık 19905 hektardan yaklaşık 21305 hektara çıktığını ve en yakın yerleşim yerlerine 1-500 metre mesafedeki maden çıkarım sahalarının alanlarının 16421 hektardan 19967 hektara çıktığını göstermiştir.

Anahtar Kelimeler: CORINE arazi örtüsü, coğrafi bilgi sistemleri, madenler, yakınlık, yerleşimler

\section{INTRODUCTION}

From the beginning of the first urbanization attempts, man chooses to live near natural resources such as rivers, food, and construction materials including minerals. What is changed in time is the size, amount, and type of production, and who gets the profits. With the industrialized urban developments, some people face the problems of mineral extraction and mass production of related products. Living near material extraction sites became unwanted because of its external effects such as pollution, health problems, and visual impacts. Local people tend to oppose mines especially when the companies get the profits and the host communities get the losses. Thus, there have been conflicts 
over mines and their locations in many cities around the World.

There is a dilemma in terms of the needs of humans. On the one hand, people want to use minerals and materials in their daily life. They need these materials in their modern life from their shelters to roads. For instance, rock minerals are indispensable materials for construction industries (Blachowski, 2014; GorniakZimroz and Pactwa, 2018). Besides, they provide raw materials for industries and support the economies of communities (Garrod and Willis, 2000). Therefore, mining is urgent for society and needs social consent (Menegaki and Kaliampakos, 2014). On the other hand, people want to live in healthy environments. They do not want mines near their living environments. They want the mines out of their settlements. Indeed, mines have to be located where the minerals exist. Therefore, their locations are not flexible (Menegaki and Kaliampakos, 2014). Besides, the mining sector wants to minimize transportation costs of mine locations far from urban settlements where the materials are used. Especially aggregate quarries select locations where both source materials exist and transportation costs are low (Robinson et al., 2004). While people need minerals for their products and development, mining may cause negative impacts on the surrounding environments (Zhang et al., 2011; Simila and Jokinen, 2018). There is a debate on the proximities of mines to settlements and their possible effects.

The success in balancing benefits from resources depends on the ability to monitor environmental impacts caused by developments (Latifovic et al., 2005; Zhang, 2011). The success in managing resources also depends on determining spatial relationships with their sites and other land uses. Resource management by policymakers requires information about the spatial distribution and the intensity of mining and this knowledge is important for planning on national, regional, and local scales (Blachowski, 2014). Previous research states that there is often close proximity between mining activities and local communities (Andrews et al., 2017). It shows the need for researches measuring the degree of this proximity in various geographic environments.

Settlements (and/or cities) and mines (and/or quarries) are two competing land uses on which stakeholders have conflicting interests (Hilson, 2002; loannidou et al., 2015; Sinthumule et al., 2020). Mines are one of the locally unwanted land uses (Steelman and Carmin, 1998; Atay Kaya and Kaya Erol, 2016). The opposition emerges while individual interests are conflicting with the collective interests (Steelman and Carmin, 1998).
The proximity is one of the factors affecting public opposition to proposed mines (van der Plank et al., 2016).

The proximity between mines and urban or rural land uses is not always caused by the expansion of mines but also caused by the expansion of urban in the direction of the pre-existing unwanted land uses (Jensen et al., 2019). Besides, the process that workers of mines move to the areas with close proximity to mines is described as "in-migration and return-migration around mining operations" (Andrews et al., 2017). Land cover change types such as development, urbanization, afforestation, and reclamation (Feranec et al., 2010) also determine and affect the proximities between mineral extraction sites and settlements.

The impacts of mining on communities could be both positive and negative according to Hilson (2002). Positive impacts are related to the wealth of socioeconomic benefits. Negative impacts include a change in the social balance after migration of non-local employees of mines and related conditions such as the spread of diseases (Hilson, 2002). Although people recognize mining as an important part of the economy, local communities in many cities around the World have negative perceptions about mines; the Australian case study is an example (van der Plank et al. 2016). Mining is important for the economy of developing countries but rarely for the local livelihoods (Sinthumule et al., 2020). Mines have benefits at the national level through an increase in jobs and taxes; however, it may affect the quality of the environment and lives of surrounding communities (McMahon and Remy, 2001; Brown et al., 2017; Simila and Jokinen, 2018). According to some scholars (Menegaki and Kaliampakos, 2014; Brown et al., 2017; Gorniak-Zimroz and Pactwa, 2018), this causes a NIMBY (not in my backyard) approach. However, the location is not flexible in resource extraction sites and it has to be where the resources are (Menegaki and Kaliampakos, 2014). Findings of a previous case study in New England, USA illustrate the importance of the proximity of aggregate quarries to urban fringes (Robinson et al., 2004). A case study in a mine in West Virginia presents a contrast situation to writings on NIMBY that the people there are mobilizing and protesting mines for common properties and community interests and not focus on their individual properties (Steelman and Carmin, 1998).

Negative impacts of mining activities on adjacent areas are the deformation of slopes and land surfaces, effects on both underground and surface water, pollution of soil, air, and water, and degraded wildlife habitats 
(Steelman and Carmin, 1998; Garrod and Willis, 2000; Menegaki and Kaliampakos, 2014; Marschalko et al., 2015; Mondal et al., 2016; Gorniak-Zimroz and Pactwa, 2018; Sinha et al., 2019; Sinthumule et al., 2020). Besides the environmental costs, mine neighboring communities are affected through health impacts (Steelman and Carmin, 1998; McMahon and Remy, 2001) related to pollution, dust, noise, and vibration (Menegaki and Kaliampakos, 2014; Atay Kaya and Kaya Erol, 2016; Mondal et al., 2016; GorniakZimroz and Pactwa, 2018; Sinthumule et al., 2020), and economic impacts related with reduced real estate values, risk of adverse effects on crops and farms, and heavy traffic (Gorniak-Zimroz and Pactwa, 2018; Sinthumule et al., 2020). The effects of being in proximity to mines include damage to structures and a decrease of property values caused by the mine subsidence (Treworgy and Hindman, 1991; Korose et al., 2009). Blasting in a quarry in Germiyan village in Izmir, Turkey is claimed to cause stones coming to the garden of the primary school (Atay Kaya and Kaya Erol, 2016). The visual impact is another problem about mines (van der Plank et al., 2016). More seriously, there are demolished villages while new mines are opened in the Czech Republic (Matejicek and Kopackova, 2010; Martinat et al., 2014). Such displacement of native communities is also a result of mines in Papua New Guinea (Hilson, 2002). There are also procedural reasons to oppose mines such as lack of trust and credibility (Steelman and Carmin, 1998; Atay Kaya and Kaya Erol, 2016; van der Plank et al., 2016).

These negative impacts cause conflicts over mines all over the World. Examples include conflicts between mining activities and the environmental protection in China (Li et al., 2015), conflicts between various stakeholders because of interference in the natural environment and health impacts in Poland (Gorniak-Zimroz and Pactwa, 2018), conflicts between mining companies and mining communities in South Africa (Matebesi and Marais, 2018). The major stakeholders are local communities, mining companies, and the central government (McMahon and Remy, 2001). Besides negative impacts, local economic benefits, job creation, rehabilitation of the mined land, community engagement, and funding are some expectations of local communities from mining companies (Matebesi and Marais, 2018). Many countries require social cost-benefit analysis for legal permissions of proposed mines (Damigos, 2006). It has taken many years of experience in Canada to eliminate and mitigate the negative effects of mines on hosting communities (McMahon and Remy, 2001). Taking precautions could only be possible after determining the conflicting situations; therefore, analysing the spatial distribution of the mines with proximity gains importance. Turkey is one of the countries facing conflicts over mines. There have been several protests of local people against mining activities. Examples include İzmir, Balıkesir, Çanakkale, Uşak, Artvin, and Niğde (Özen and Özen, 2010). With an awareness that proximity to settlements is one of the important reasons for mining conflicts, this study measures them and finds out the spatial distribution of mines with different proximities to settlements.

Urban planning deals with conflicts over locally unwanted land uses such as mines. Mining corporations have an impact on urban plans via their developing and declining decisions affecting urban dynamics and mining communities (Martinez-Fernandez et al., 2012). Territories of mineral resources should be properly planned based on the legislation to control the environmental impacts of mining (Sudoniene and Atkoceviciene, 2013). Land use decisions regarding the proximities of the mineral extraction sites and other land uses with various negative externalities to the vulnerable settlements should include a process determining and monitoring land cover changes.

The Coordination of Information on the Environment (CORINE) is a project of the European Union aiming to monitor land cover changes in a cross-border context (EEA, 2017). CORINE Land Cover (CLC) datasets are useful in assessing the changes in land cover in the European context (Feranec et al., 2010). Turkey is one of the countries having CORINE land cover data and sharing it in a portal of the Republic of Turkey Ministry of Agriculture and Forestry (TMAF, 2018). A review of Turkish studies using the CORINE data found that there are 32 studies and most of them are in the research area of agricultural engineering and forest engineering and that all the reviewed articles have studied a city or a geographic unit such as a delta or a basin (Karakaş Özür and Ataol, 2018). A broader study includes 48 cities focusing on the pastures (Mermer et al., 2012). Apart from this review, studies are using CORINE data at the country-level to understand the dynamics of land use and land cover changes (Ustaoglu and Aydınoglu, 2019; Yılmaz Genç et al., 2021) and to assess various land uses such as agricultural lands (Bayar, 2018), and airports (Özür, 2018). This current study using data covering the whole country is one of the rare researches with such broad scope. Although the proximity of mines to settlements and their effects have been studied in various geographies, the efforts of proximity analysis in the countrywide scale remain limited. This study contributes to geosciences and land use planning focusing on mining land cover with its broad scale in the Turkish context. 
Previous studies utilized GIS and remote sensing methods and CORINE data. Remote sensing provides a cost-effective way to detect landscape changes around large mines (Paull et al., 2006). However, it is argued that remote sensing is under-utilized in the mining sector (Latifovic et al., 2005). Indeed, remote sensing has been a tool for the analysis of mining lands. Some studies performed land use and land cover change analysis and comparing two or more years in terms of land uses affected by mineral extraction in their case studies including certain mines (Paull et al., 2006; Matejicek and Kapockova, 2010; Petropoulos et al., 2013; Li et al., 2015; Mondal et al., 2016; Jensen et al., 2019). Examples of GIS-based studies monitor the changes in the impacts around a mine site in Maharashtra (Sinha et al., 2019) and calculate the mining density and its change in time and distances from dwelling in a region of Poland (Blachowski, 2015). Some studies used CORINE land cover classes in their image classification processes (Matejicek and Kapockova, 2010, loannidou et al., 2015) and prefer these sources because of public availability and acknowledged quality of CORINE data (loannidou et al., 2015).

This research seeks to answer "How far are mines to settlements in Turkey in 2012 and 2018?' The subquestions are "How did the distribution of mines "near" settlements change between the years 2012 and 2018 in the country?' and "Which cities in Turkey are prone to proximity to mineral extraction sites?". To answer these questions, this study uses remotely sensed layers of mineral extraction sites and urban settlements of the CORINE land cover dataset. Their distances to each other are calculated by using ArcGIS 10.6 software. Then, the thematic maps are produced and interpreted.

\section{MATERIALS AND METHODS}

The data used in this study includes feature classes of mineral extraction sites and urban settlements in Turkey for the years 2012 and 2018 (Figure 1). "Mineral extraction sites" in this map refer to the polygons with codes of 131 in CORINE legend and "settlements" refer to both continuous urban fabric (with code 111) and discontinuous urban fabric (with code 112). The years of the data are the recent publicly shared data in the sources. The sources of the data are the portals of the Republic of Turkey Ministry of Agriculture and Forestry (TMAF, 2018) and the Copernicus Land Monitoring Service (2020). The boundaries of cities in Turkey are downloaded from the portal of the same ministry (TMAF, 2018). They are exported to a personal geodatabase. The features with related codes $(131,111$, and 112) are selected by attributes and collected as new layers of mines (131) and settlements (111 and 112). The data includes 1427 polygons for the year 2012 and 1817 polygons for the year 2018 in the mines layer, 10926 polygons for the year 2012 and 11789 polygons for the year 2018 in the settlements layer, and 81 polygons in the cities layer.

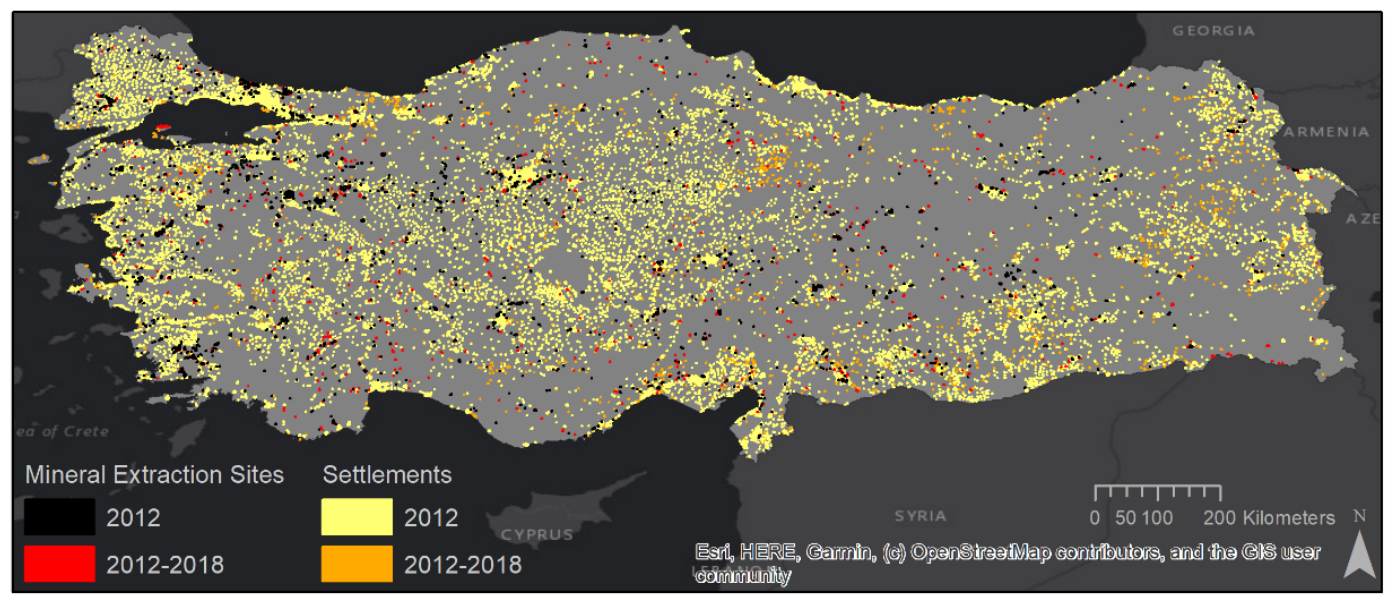

Figure 1. Mineral extraction sites and settlements in Turkey (map produced by the author with data from CLC2012 and CLC2018 on the base map of ArcMap)

The analysis method includes calculation, classification, joining relations, visualizing, and comparing steps (Figure 2). In the calculation step, the "near" tool of ArcGIS is used for the layer "mines". This tool produces a list including information on the nearest feature class (here it is "settlements") from the selected feature class (here it is "mines") and the distance to the nearest feature. The 
method of measurement is selected as geodesic distance because the input data is in a geographic coordinate system.

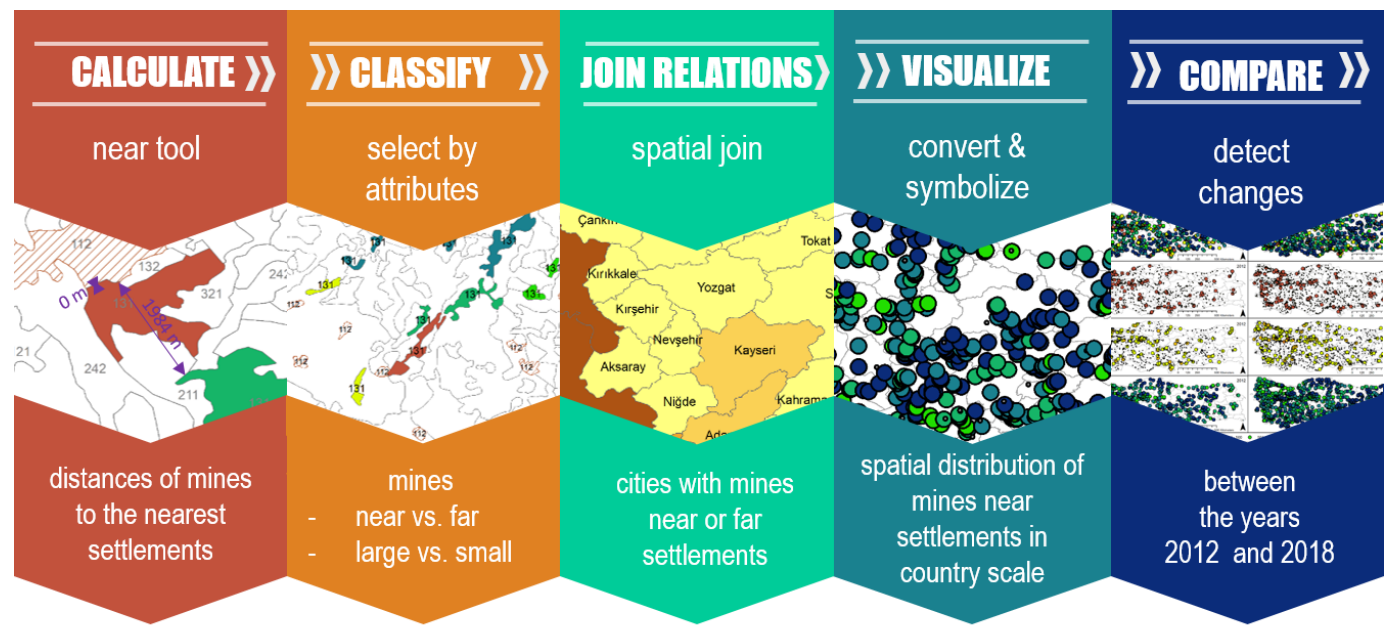

Figure 2. Research design

The classification step grouped the mines in terms of their distances to settlements. The classes include mines neighbouring settlements (where the distance is equal to zero), mines within a distance below 60 meters, mines within a distance between 61 meters and $150 \mathrm{me}-$ ters, between 151 meters and 500 meters, 501 and 1000, 1001 and 2000, 2001 and 4000, and finally 4001 and above (Figure 3). The intervals of 1000, 2000 and 4000 meters are selected based on previous researches (Walker et al., 2005; Higgs and Landford, 2009) and other intervals are determined based on the present reg- ulations in Turkey. The $117^{\text {th }}$ article of the mining regulation (published in the Official Gazette with number 30187 and date 21.9.2017) based on the Mining Law (with number 3213 and date 4.6.1985) requires additional permissions for the mines located within 60 meters to public services such as schools, hospitals, and libraries. The 26th article of the same regulation limits certain types of mining activities (i.e. those performing blasting) within 500 meters to planned urban zones and 150 meters to these zones if the mine is out of the visible scenes. Thus, 60, 150, and 500 meters are classified separately.

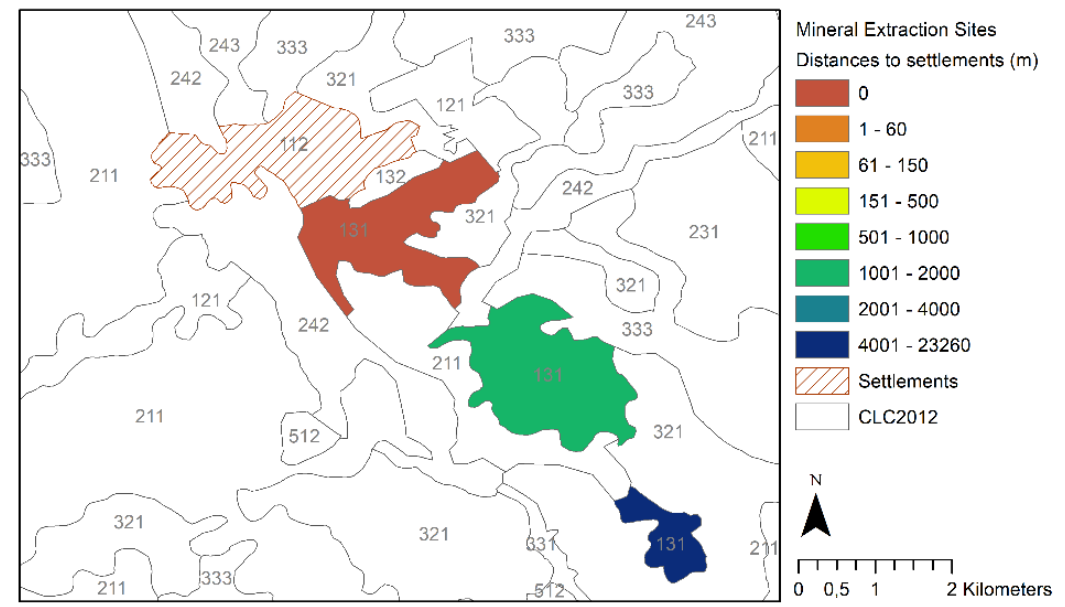

Figure 3. Example of the classified mines after calculation of their distances to settlements 
In the classification step, mines are also classified in terms of their sizes. Two groups are determined depending on the Appendix with number 1 of the Environmental Impact Assessment Regulation of Turkey (published in the Official Gazette with number 29186 and date 25.11.2014). There are two types of mines based on their sizes in this regulation: mines larger than 25 hectares of area and mines larger than 150 hectares of area.

The regulations also include various types of mines according to their production amounts, process methods, and material types; however, this study does not consider these characteristics because of the chosen data type. The collected data in this study considers only open extraction sites that can be observed through remote sensing methods. Thus, underground mines are omitted in this study.

In the following step, the "cities" layer is spatially joined to the classified mines layer. The "spatial join" tool of ArcGIS is used in this step to relate the quantitative information of a spatial feature as attributes of another spatial feature. The attribute table of the mines layer with the city information is exported to Excel. Then, the number of mineral extraction sites, total area of mines, and the average distance of mines to settlements are calculated. Besides, the number of mineral extraction sites neighbouring settlements, the number of mineral extraction sites within 500 meters to settlements, and the number of mineral extraction sites far more than 500 meters from settlements within the city boundaries are calculated for each city. The new table is converted to a table and joined to the cities layer in ArcGIS. This process provides an opportunity to interpret the proximities of mines depending on the cities they locate and to compare cities.

The visualization step includes producing thematic maps of the analysis results. The map showing the distribution of original polygons of the mines seems visually poor because of the difficulty of distinguishing classes on the country scale. Thus, they are converted to point features and symbolized according to their proximities calculated by the near tool. Besides, the maps showing cities are visualized by using monochromatic colours to highlight the features with the highest and the lowest values.

The final step of the study is the comparison of the results for the years 2012 and 2018. In this step, changes between these years are detected and the differences are interpreted. This study does not aim to understand the reasons for these changes. Rather, it determines the settlements with close proximity to mineral extraction sites on a country scale and compares two years to understand if they are decreased or increased.

\section{FINDINGS}

Turkey is one of the first 20 countries with the highest value of produced mines excluding fuels (UMREK, 2020). The rank of the country is $10^{\text {th }}$ in global mineral diversity according to the Presidency of the Republic of Turkey (INVEST, 2020). The same reference reports that Turkey's share in global industrial raw material reserves is $2.2 \%$; in global natural stone reserves is $40 \%$; in global boron reserves is $73 \%$. There is an increase in foreign investment in the mining sector in Turkey (INVEST, 2020).

The total area of mineral extraction sites in Turkey increased from nearly 112587 hectares to 142662 hectares from 2012 to 2018 according to CORINE land cover data (Table 1). The mineral extraction sites adjacent to settlements increased from nearly 19905 hectares to nearly 21305 hectares from 2012 to 2018 . They are $18 \%$ of the total mineral extraction area in 2012 whereas $15 \%$ of the total mineral extraction area in 2018. Mineral extraction sites that are not adjacent but within 500 meters to settlements increased from nearly 16421 hectares of area (15\% of the total mineral extraction area in 2012) to nearly 19967 hectares of area (13.2\% of the total mineral extraction area in 2018). Those within distances between 500 meters and 4 kilometres to settlements are 56203 hectares of the area in 2012 whereas they are 71465 hectares of area in 2018. Mines located far more than 4 kilometres from settlements are increased from $18 \%$ of the total mineral extraction areas in 2012 to $21 \%$ in 2018. 
Table 1. Amounts and areas of mineral extraction sites grouped in terms of their distances to settlements in Turkey in the years 2012 and 2018

\begin{tabular}{lcccccccc}
\hline $\begin{array}{l}\text { Distance } \\
\text { between } \\
\text { mines and } \\
\text { settlements }\end{array}$ & \multicolumn{2}{c}{$\begin{array}{c}\text { Number of } \\
\text { mines }\end{array}$} & \multicolumn{2}{c}{$\begin{array}{c}\text { Percentage of } \\
\text { number of mines }\end{array}$} & Area (ha) of mines & \multicolumn{2}{c}{$\begin{array}{c}\text { Percentage of the } \\
\text { area of mines }\end{array}$} \\
\cline { 2 - 9 } & 2012 & 2018 & 2012 & 2018 & 2012 & 2018 & 2012 & 2018 \\
\hline 0 & 132 & 124 & $9.3 \%$ & $6.8 \%$ & 19905.4 & 21304.9 & $17.7 \%$ & $14.9 \%$ \\
$1-60$ & 2 & 5 & $0.1 \%$ & $0.3 \%$ & 935.4 & 299.6 & $0.8 \%$ & $0.2 \%$ \\
$61-150$ & 32 & 41 & $2.2 \%$ & $2.3 \%$ & 3594 & 4901.2 & $3.2 \%$ & $3.4 \%$ \\
$151-500$ & 128 & 152 & $9.0 \%$ & $8.4 \%$ & 11891.2 & 14765.9 & $10.6 \%$ & $10.4 \%$ \\
$501-1000$ & 153 & 187 & $10.7 \%$ & $10.3 \%$ & 10046.6 & 13437.2 & $8.9 \%$ & $9.4 \%$ \\
$1001-2000$ & 266 & 345 & $18.6 \%$ & $19.0 \%$ & 23877.2 & 26603.3 & $19.8 \%$ & $18.6 \%$ \\
$2001-4000$ & 362 & 451 & $25.4 \%$ & $24.8 \%$ & 22279.2 & 31424.8 & $21.2 \%$ & $22.0 \%$ \\
+4001 & 352 & 510 & $25.7 \%$ & $28.1 \%$ & 20058.2 & 29925.1 & $17.8 \%$ & $21.0 \%$ \\
\hline Total & 1427 & 1815 & $100 \%$ & $100 \%$ & 112587.4 & 142662 & $100 \%$ & $100 \%$ \\
\hline
\end{tabular}

The number of mines neighbouring settlements are decreased from 132 to 124 in Turkey from 2012 to 2018 whereas the area of those mines increased by nearly 1400 hectares. These mine neighbouring settlements are mostly discontinuous urban fabric $(98 \%)$ which are coded 111 in CORINE legend. Only $2 \%$ of them are continuous urban fabric which is coded 112 in CORINE legend. Examples from mines neighbouring settlements show the proximity of mines in three example cities (Figure 4).
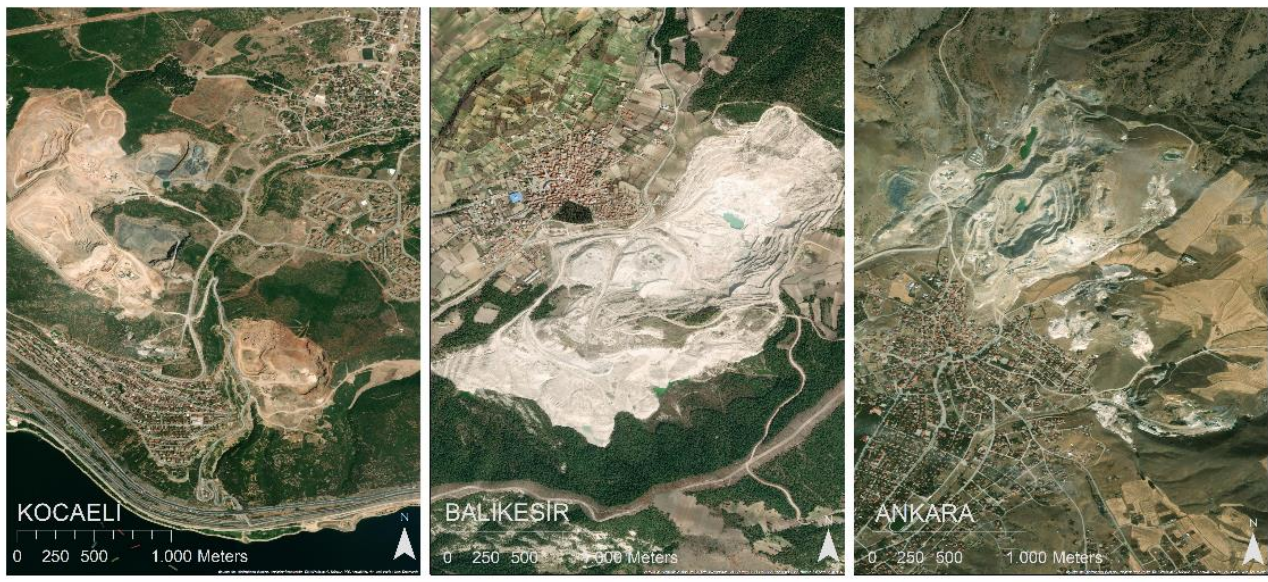

Figure 4. Examples from mines neighboring settlements in Turkey (the base map of ArcMap)

The spatial distribution map of classified mineral extraction sites in Turkey (Figure 5) is interpreted with the support of the map of the points produced from the same data based on CLC2012 (Figure 6). These maps show that mines neighbouring settlements are located mostly in the Western and Southern parts of the country in both 2012 and 2018. In the eastern and north-eastern parts of the country, mineral extractions sites are mostly far more than 500 meters from the settlements. The mineral extraction sites in the middle Anatolia have various distances to the settlements. 


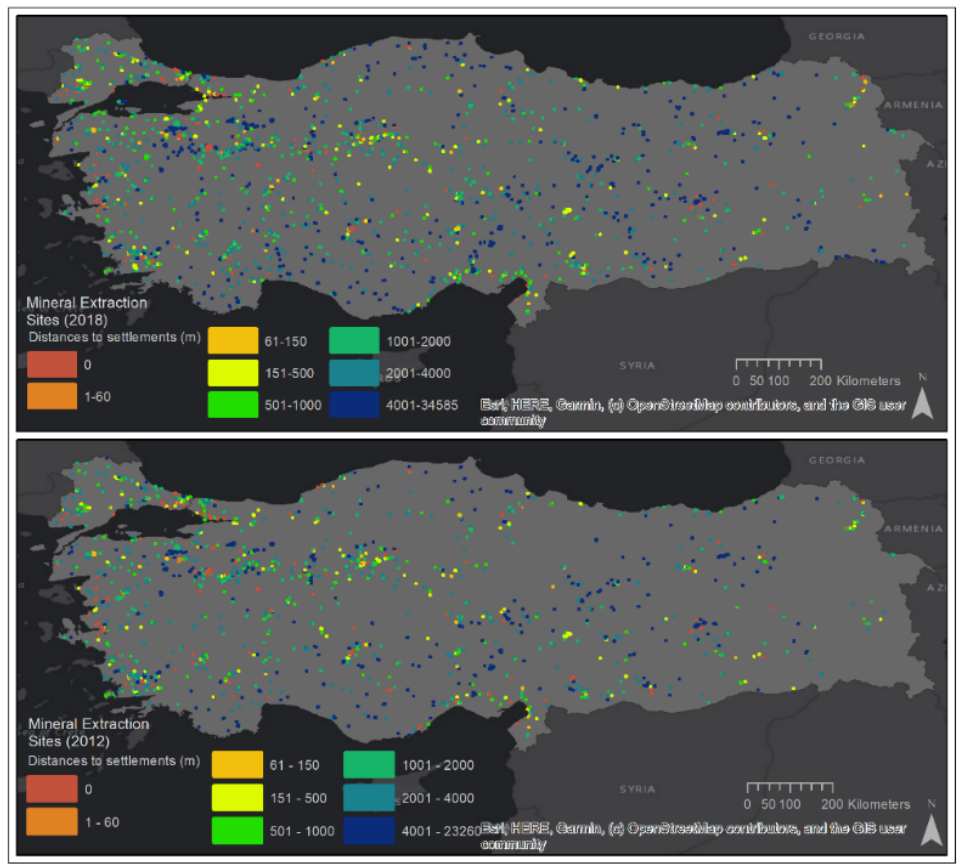

Figure 5. Spatial distribution of mines with classified distances to settlements in Turkey (maps produced by the author by using data from CLC 2012 and CLC2018 on the base map of ArcMap)

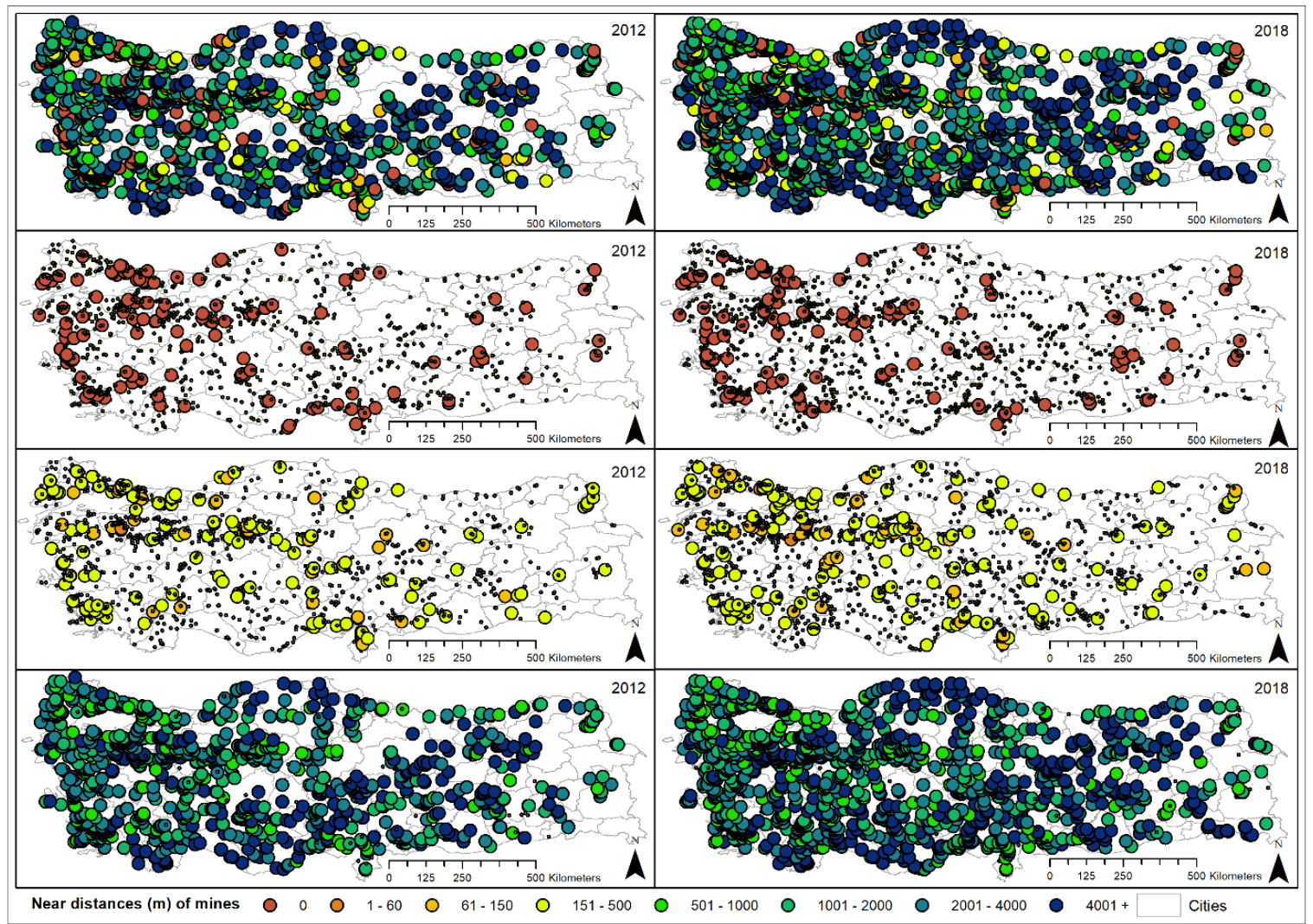

Figure 6. Distribution of mine points with classified distances to settlements in Turkey in the years 2012 (left) and 2018 (right) (1 ${ }^{\text {st }}$ row: all mines, $2^{\text {nd }}$ row: mines neighboring settlements, $3^{\text {rd }}$ row: mines within 1-500 meters to settlements, $4^{\text {th }}$ row: mines far than 500 meters to settlements) 
The smallest area of the mineral extraction sites in CLC2012 and CLC2018 data of Turkey is 25 hectares. The reason is that the minimum mapping unit is 25 hectares in the CORINE database (Büttner, 2014). The number of mines between 25 and 150 hectares ("smaller mines" until now in this paper) increased from 1317 (92\% of the total) in 2012 to 1679 (7\% of the total) in 2018. The number of mines larger than 150 hectares ("larger mines" until now in this paper) is increased from $110(8 \%)$ in 2012 to 136 (93\%) in 2018. The comparison of numbers of larger and smaller mines (Figure 7) presents that the highest number of larger mines is neighbouring settlements in both 2012 and 2018 whereas the
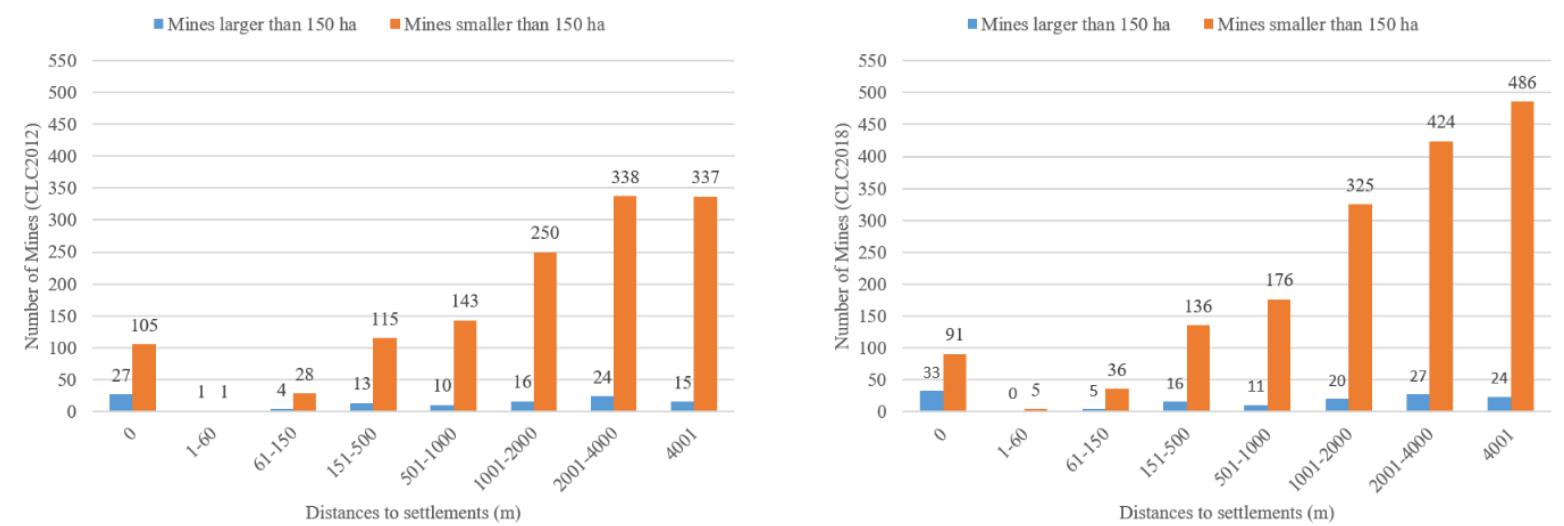

Figure 7. Comparison of numbers of larger and smaller mines within various distances to settlements for the years 2012 (left) and 2018 (right)

After joining the spatial and attribute information of mineral extraction sites, maps showing cities in terms of their mine amounts, mine areas (Figure 8), and mine proximities (Figure 9) are produced. There are no mineral extraction sites in three cities (Ağrı, Hakkari, Kilis) according to CLC2012 of Turkey, whereas all cities in the country have mineral extraction sites according to CLC2018 data. The biggest number of mines are located in cities of Ankara, İstanbul, Konya, Eskişehir, Bursa, and Muğla in both 2012 and 2018. The cities located in the eastern and northern parts of middle Anatolia have a relatively smaller number of mines. The largest total mining area is located in the city of Kütahya in both years. The number of cities with a total area of mining highest numbers of smaller mines are within 2001-4000 meters to settlements and more than 4000 meters to settlements. Nearly a quarter of the larger mines (27 of 110 mines in 2012 and 33 of 136 mines in 2018) are neighbouring settlements. The ratio of larger mines in total mineral extraction sites neighbouring settlements increased from $20 \%$ to $27 \%$ from 2012 to 2018 . The difference between the number of smaller and the number of larger mines is relatively big in distances more than 150 meters. above 5000 hectares increased from 7 to 9 from 2012 to 2018.

The average mining proximity is the smallest $(94,5 \mathrm{~m})$ in Batman in 2012 (top-left in Figure 9), whereas the average proximity increased to 448 meters in Batman in 2018 and the smallest average mining proximity in the country increased to 356 meters and located in Ağrı in 2018. The only city having the average proximity of mines to settlements between 150 and 500 meters is Ordu (461 m) in 2012, whereas the cities having the average proximities between 150 and 500 meters are Ağrı, Batman, Yalova, and Kocaeli in 2018 ( $1^{\text {st }}$ row in Figure 9). 


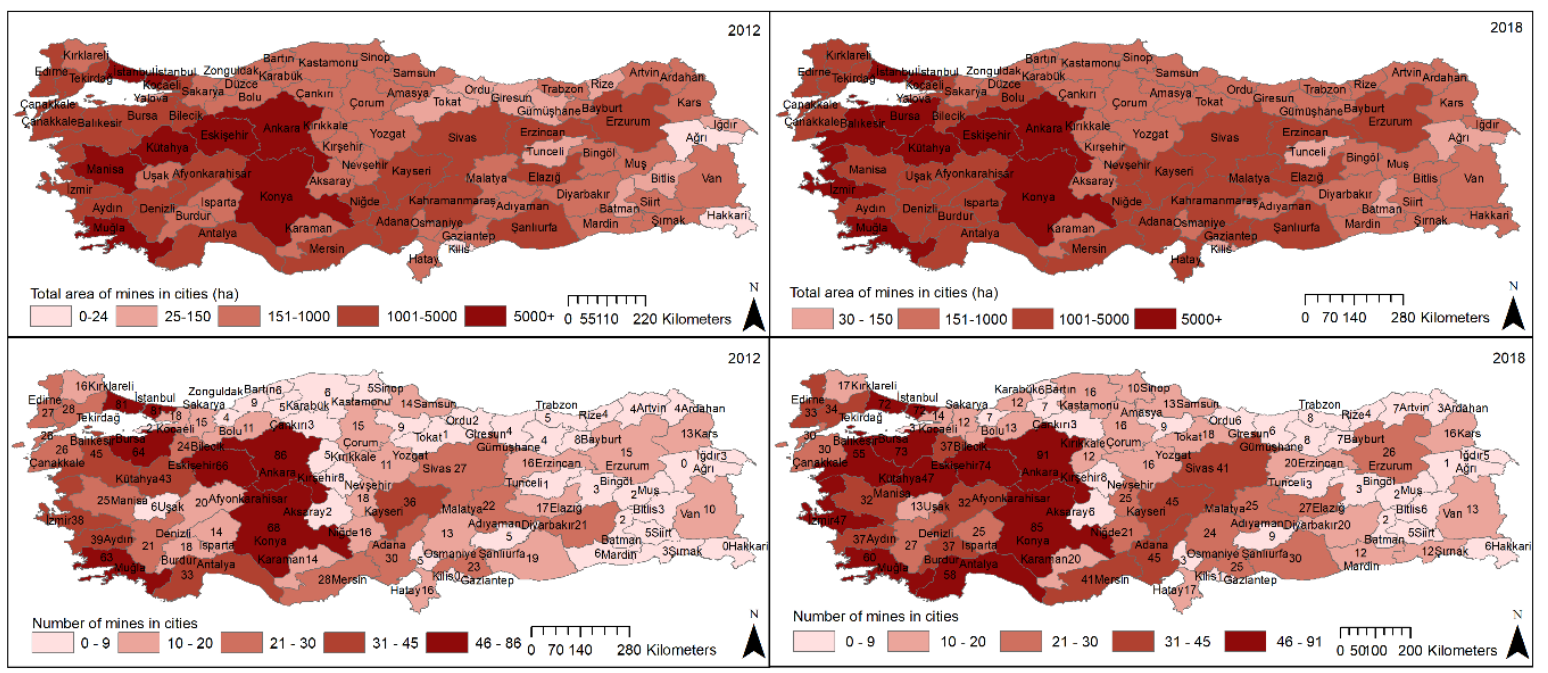

Figure 8. The total area of mines (top) and the number of mines (bottom) in cities of Turkey in the years 2012 (left) and 2018 (right)

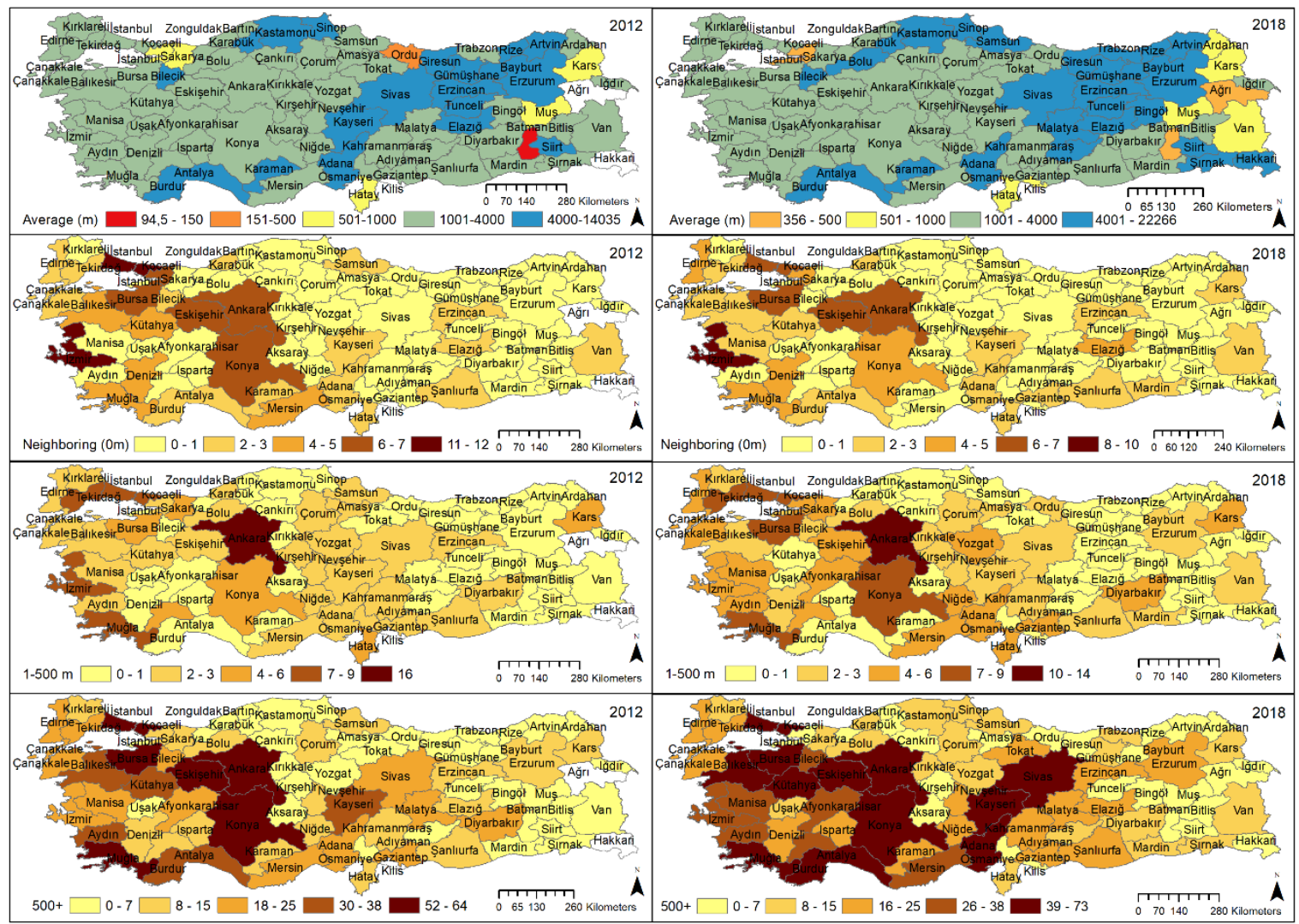

Figure 9. Cities of Turkey classified in terms of the distances of mines to settlements in the years 2012 (left) and 2018 (right) ( $1^{\text {st }}$ row: average distance of mines, $2^{\text {nd }}$ row: mines neighboring settlements, $3^{\text {rd }}$ row: mines within 1-500 meters to settlements, $4^{\text {th }}$ row: mines far than 500 meters to settlements) 
Cities including the largest amount of mines neighbouring settlements are shown in dark colours on the map (2nd row in Figure 9). There are at least one mine neighbouring settlements in 48 cities in 2012 and 46 cities in 2018. From these cities, Izmir has the highest number of mines neighbouring settlements in both 2012 and 2018 . İstanbul, Eskişehir, Ankara, and Bursa are following with 6-7 mines neighbouring settlements in both years.

27 mines (2\% of the 1427 mines in total) in 2012 and 33 mines (2\% of the 1815 mines total) in 2018 are both larger than 150 hectares and have zero distance to the settlements. The largest one is located in Kütahya and increased from nearly 4830 hectares in 2012 to nearly 5084 hectares in 2018 . The following largest mineral extraction site (nearly 1100 hectares) adjacent to settlements is located in Muğla. The third-largest mine neighbouring settlements is in Eskişehir in 2012 whereas the mine with the third rank is in Bursa in 2018.

Cities including the largest amount of mines within a distance between 1 and 500 meters are in Ankara in both 2012 and 2018 (3rd row in Figure 9). It is followed by İstanbul, Izmir, Muğla, and Tekirdağ in 2012 and Tekirdağ, Bursa, İstanbul, and Konya in 2018. Cities including more than 30 mines far than 500 meters are located mostly in the western part of the country ( $4^{\text {th }}$ row in Figure 9). All mines are located more than 500 meters of settlements in 15 cities (19\% of the 81 cities) in 2012 and 13 cities (16\% of the 81 cities) in 2018.

\section{DISCUSSION}

The proximity of mines to settlements can be an indicator of possible future conflicts. The findings of this study showed that there are 132 mines in 2012 and 124 mines in 2018 adjacent to settlements and 162 mines in 2012 and 198 mines in 2018 with proximities below 500 meters to settlements which may cause conflicts between the people living there and mining firms. However, the existence of the problem does not always end with conflict. There are some situations in which mining firms bargain with local communities, especially in villages. They use strategies to prevent conflicts before they happen. For example, the mining firms propose gifts for villagers such as investments in schools and mosques, and construction materials (Atay Kaya and Kaya Erol, 2016). By doing this, they aim to guarantee public acceptance in the participation meetings of Environmental Impact Assessment processes.

The proximity of mines to living environments is not the only reason for conflicts over mines. The nature and size of conflicts depend on the type of mining, size of extraction, and the technologies used in mining processes
(Gorniak-Zimroz and Pactwa, 2018). Besides, mines with different types have different impacts. Moreover, the extent of activity in mines also affects the impacts and related conflicts. Not only the active mines but also the abandoned mines could be a reason for disamenity. The importance of the restoration of the abandoned mines is widely emphasized (Garrod and Willis, 2000; Blaen et al., 2015; Sinnett, 2019; Zou, 2019). The data used in this study did not include information about the types and activity levels of the mines. The remotely sensed land cover data collect information depending on the visual characteristics of lands; therefore, the mineral extraction sites in this analysis may contain inactive mines that have been closed but not rehabilitated yet. This study provides a step for the further detection of mineral extraction sites for the control of the responsible institutions. According to the statistics of the General Directorate of Mining and Petroleum Affairs of Turkey (MAPEG, 2020), there are 12945 exploration licenses and 13068 operation licenses in Turkey. Indeed, the amount of these mining licenses shows the possible increase in the future mining extraction sites and the possible increase in the mines with proximity to settlements. The results of this study provide evidence of the increase in both the total area of mineral extraction sites from 2012 to 2018 and the area of the mineral extraction sites neighbouring settlements. Future changes in land cover will continue to be a subject of planning professionals. Land use planning processes should include solutions to reconcile the interests of different land uses (Simila and Jokinen, 2018).

There are limitations of accuracy and possible errors in data collected with remote sensing methods (Latifovic et al., 2005; Paull et al., 2006; Li et al., 2015). However, remote sensing facilitates the analyses in large area coverage with remote locations (Latifovic et al., 2005; Paull et al., 2006). Using CORINE data of Turkey in this study made it possible to analyse all mines and their proximities in a relatively easy and fast way. Indeed, it is a great opportunity to find such large data from open data portals.

GIS provides useful analysis tools for researchers exploring the proximity of land uses. Previous studies aiming to determine the proximities of mines to urban areas in Illinois used buffer analysis of GIS for two different distances (Treworgy and Hindman, 1991; Korose et al., 2009). It is a useful method to identify a certain distance to draw an area around mines. This current study on Turkey did not prefer this method because the process would require an additional step to select the urban land uses within this buffer. By using the near method, this study determined the nearest polygons of urban land 
use and then classified them according to predetermined groups. The use of buffer would require five times analysis for each distance including 60, 150, 500, 1000, and 4000 meters. There is another study performing multiple ring buffer analyses for five different distances (Jensen et al., 2019); however, in this study, not only point features but also original shapes of mines are considered; therefore, the ring buffer is not selected as an analysis method. Thus, the choice of near or buffer analysis should vary depending on the aims and scope of studies.

\section{CONCLUSION}

Communities need materials and minerals extracted in mines to construct their shelters, roads, and other daily needs but local people do not want mines near themselves. The proximity between mines and settlements is an indicator of the possible externalities of mining activities.

The main conclusions of this research are as follows: (i) In Turkey, $9 \%$ of the mines (19905 hectares) in 2012 and $7 \%$ of the mines (21305 hectares) in 2018 are located next to settlements in 48 cities in 2012 and 46 cities in $2018,11,1 \%$ of mines in 2012 and $10,3 \%$ of mines in 2018 are within 1-500 meters to the nearest settlements, and the rest of mines $(80,9 \%$ in 2012 and $82,7 \%$ in 2018) are far from 500 meters in cities distributed to the various parts of the country. There are smaller numbers of mines with proximity to settlements in the eastern and northern parts of the country in both 2012 and 2018. The area of mines adjacent to settlements is increased from nearly 19905 hectares to nearly 21305 hectares from 2012 to 2018. (ii) Both larger and smaller mines are located in proximity to settlements in Turkey both in 2012 and 2018. The mines that are both adjacent to settlements and larger than 150 hectares increased from $20 \%$ to $27 \%$ from 2012 to 2018. (iii) CORINE land cover data is useful in a general measurement of the proximity of mines to settlements on a country scale.

Not only the proximity and sizes of mines but also their type and the precautions taken there are important determinants in causing external effects. It is a limitation of this study that these other factors could not be considered because of the type and scale of the data. Future studies may engage remotely sensed data with the data collected in the fieldwork.

As another limitation of this study, the data may have errors because of using remotely sensed CORINE data. However, open geospatial data collected from online resources make the researches on country scales fast and manageable. Thus, the CORINE project and similar platforms contribute to many fields of science including engineering, geography, urban and regional planning and so on.

\section{ACKNOWLEDGMENTS}

The author acknowledges the European Environment Agency, the European Union, and the Republic of Turkey Ministry of Agriculture and Forestry for producing and sharing the CORINE data.

\section{KAYNAKLAR}

Andrews, T., Elizalde, B., Le Billon, P., Oh, C. H., Reyes, D., Thomson, I. (2017). Chapter 2: Literature review, In Andrews, T. et al. (eds.) The rise in conflict associated with mining operations: What lies beneath? Canadian International Resources and Development Institute (CIRDI) (1731). Washington, DC, USA.

Atay Kaya, İ., Kaya Erol, N. (2016). Conflicts over Locally Unwanted Land Uses (LULUs): Reasons and solutions for case studies in Izmir (Turkey). Land Use Policy, 58: 83-94.

Bayar, R. (2018). Arazi kullanımı açısından Türkiye'de tarım alanlarının değişimi, Coğrafi Bilimler Dergisi 16(2): 187200.

Blachowski, J. (2014). Spatial analysis of the mining and transport of rock minerals (aggregates) in the context of regional development. Environmental Earth Sciences, 71(3): 1327-1338.

Blachowski, J. (2015). GIS-Based spatial assessment of rock minerals mining - A case study of the Lower Silesia Region (SW Poland). Mining Science, 22: 7-22.

Blaen, P. J., Jia, L., Peh, K. S. H., Field, R. H., Balmford, A., MacDonald, M. A., Bradbury, R. B. (2015). Rapid assessment of ecosystem services provided by two mineral extraction sites restored for nature conservation in an agricultural landscape in Eastern England. PLoS ONE, 10(4): 120.

Brown, G., Kangas, K., Juutinen, A., Tolvanen, A. (2017). Identifying environmental and natural resource management conflict potential using participatory mapping. Society and Natural Resources, 30(12): 1458-1475.

Büttner, G. (2014). CORINE Land cover and land cover change products. Chapter 5 in Manakos, I. \& Braun M. (eds.) Land use and land cover mapping in Europe. Springer Netherlands, 55-74.

Copernicus Land Monitoring Service (2020). CORINE Land Cover (CLC) 2018, Version 2020_20u1. the European Environment Agency, the European Union. https://land.copernicus.eu/pan-european/corine-land-cover/clc2018 (Accessed Date: 14 November 2020).

Damigos, D. (2006). An overview of environmental valuation methods for the mining industry. Journal of Cleaner Production, 14(3-4): 234-247.

EEA (2017). Landscapes in transition: An account of 25 years of land cover change in Europe, European Environment Agency, Report No:10/2017. https://www.eea.europa.eu/publications/landscapes-in-transition (Accessed Date: 30 January 2020). 
Environmental impact assessment regulation of Turkey (published in the Official Gazette with number 29186 and date 25.11.2014).

Feranec, J., Jaffrain, G., Soukup, T., Hazeu, G. (2010). Determining changes and flows in European landscapes 19902000 using CORINE land cover data. Applied Geography, 30: 19-35.

Garrod, G. D., Willis, K. G. (2000). Economic approaches to valuing the environmental costs and benefits of mineral and aggregate extraction. Minerals \& Energy, 15: 12-20.

Górniak-Zimroz, J., Pactwa, K. (2018). Dimension and crushed stones extraction as a source of social and environmental conflicts in Poland. Minerals, 8(10): 453 https://doi.org/10.3390/min8100453.

Higgs, G., Langford, M. (2009). GIScience, environmental justice, \& estimating populations at risk: The case of landfills in Wales. Applied Geography, 29: 63-76.

Hilson, G. (2002). An overview of land use conflicts in mining communities, Land Use Policy 19: 65-73.

INVEST (2020). Presidency of the Republic of Turkey Investment Office. Sectors: Mining \& Metals. https://www.invest.gov.tr/en/sectors/pages/mining-and-metals.aspx (Accessed Date: 30 January 2020).

loannidou, D., Nikias, V., Brière, R., Zerbi, S., Habert, G. (2015). Land-cover-based indicator to assess the accessibility of resources used in the construction sector. $R e$ sources, Conservation and Recycling 94: 80-91.

Jensen, D., Baird, T., Blank, G. (2019). New landscapes of conflict: land-use competition at the urban-rural fringe. Landscape Research, 44(4): 418-429.

Karakaş Özür, N., Ataol, M. (2018). Türkiye'de Corine verilerinin kullanılmasına dair değerlendirme. ÇKÜ Journal of Institute of Social Sciences, 9(2): 110-130.

Korose, C. P., Louchios, A. G., Elrick, S. D. (2009). The proximity of underground mines to urban and developed lands in Illinois. https://www.isgs.illinois.edu/sites/isgs/files/files/coal-maps/c575.pdf (Accessed Date: 3 April 2020).

Latifovic, R., Fytas, K., Chen, J., Paraszczak, J. (2005). Assessing land cover change resulting from large surface mining development. International Journal of Applied Earth Observation and Geoinformation, 7(1): 29-48.

Li, N., Yan, C. Z., Xie, J. L. (2015). Remote sensing monitoring recent rapid increase of coal mining activity of an important energy base in northern China, a case study of Mu Us Sandy Land, Resources. Conservation and Recycling, 94: 129-135.

MAPEG (2020). General Directorate of Mining and Petroleum Affairs of Turkey, Mining statistics http://www.mapeg.gov.tr/maden_istatistik.aspx (Accessed Date: 30 January 2020).

Marschalko, M., Yilmaz, I., Kubečka, K., Bouchal, T., Bednárik, M., Drusa, M., Bendová, M. (2015). Utilization of ground subsidence caused by underground mining to produce a map of possible land-use areas for urban planning purposes. Arabian Journal of Geosciences, 8(1): 579-588.

Martinát, S., Navrátil, J., Dvořák, P., Klusáček, P., Kulla, M., Kunc, J., Havlíček, M. (2014). The expansion of coal mining in the depression areas - A way to development? $\mathrm{Hu}$ man Geographies 8(1): 5-15.

Martinez-Fernandez, C., Wu, C. T., Schatz, L. K., Taira, N.
Vargas-Hernandez, J. G. (2012). The shrinking mining city: urban dynamics and contested territory. International Journal of Urban and Regional Research, 36(2): 245-260.

Matebesi, S., Marais, L. (2018). Social licensing and mining in South Africa: Reflections from community protests at a mining site. Resources Policy, 59: 371-378.

Matejicek, L., Kopackova, V. (2010). Changes in croplands as a result of large scale mining and the associated impact on food security studied using time-series Landsat images. Remote Sensing 2(6): 1463-1480.

McMahon, G., Remy, F. E. (2001). Large mines and the community: Socioeconomic and environmental effects in Latin America, Canada, and Spain. Ottawa, Canada: International Development Research Centre. http://ovidsp.ovid.com/ovidweb.cgi?T=JS\&CSC=Y\&NEWS=N\&PAGE=fulltext\&D=ec on\&AN=0621237 (Accessed Date: 3 April 2020).

Menegaki, M., Kaliampakos, D. (2014). Dealing with NIMBYism in mining operations. In Drebenstedt, C. \& Singhal, R. (eds.), Mine planning and equipment selection. Switzerland: Springer, 1437-1446.

Mermer, A., Ünal, E., Aydoğdu, M., Urla, Ö., Yıldız, H., Torunlar, H., Avağ, A., Tuğaç, M.G., Özaydın, K.A., Dedeoğlu, F., Aydoğmuş, O. (2012). Uydu görüntüleri kullanilarak mera alanlarinin belirlenmesi. Tarım Bilimleri Araştırma Dergisi, 5(2): 107-110.

Mining Law of Turkey (with number 3213 and date 4.6.1985).

Mining Regulation of Turkey (published in the Official Gazette with number 30187 and date 21.9.2017).

Mondal, S., Maiti, K. K., Chakravarty, D., Bandyopadhyay, J. (2016). Detecting risk buffer zone in open-cast mining areas: a case study of Sonepur-Bajari, West Bengal, India. Spatial Information Research, 24(6): 649-658.

Özen, H., Özen, Ş. (2010). Kamu siyasalari ve toplumsal hareketler: Türkiye'de protesto hareketlerinin madencilik siyasasina etkileri. Amme Idaresi Dergisi, 43(2): 33-64.

Özür, N. (2018). Türkiye'de havalimanlarının kuruluş yerlerinin sürdürülebilir arazi kullanımı bakımından değerlendirilmesi. Turkish Geographical Review, 71: 15-26.

Paull, D., Banks, G., Ballard, C., Gillieson, D. (2006). Monitoring the environmental impact of mining in remote locations through remotely sensed data. Geocarto International, 21(1): 33-42.

Petropoulos, G.P., Partsinevelos, P., Mitraka, Z. (2013). Change detection of surface mining activity and reclamation based on a machine learning approach of multi-temporal Landsat TM imagery. Geocarto International, 28(4): 323-342.

Robinson, G. R., Kapo, K. E., Raines, G. L. (2004). A GIS analysis to evaluate areas suitable for crushed stone aggregate quarries in New England, USA. Natural Resources Research, 13(3): 143-159.

Similä, J., Jokinen, M. (2018). Governing conflicts between mining and tourism in the Arctic. Arctic Review on Law and Politics, 9: 148-173.

Sinha, S., Chakraborty, S., Shome, D. (2019). Mining footprint: a spatial indicator of environmental quality - a case study of a manganese mine in Bhandara district, Maharashtra. Arabian Journal of Geosciences, 12(96); https://doi.org/10.1007/s12517-019-4260-0.

Sinnett, D. (2019). Going to waste? The potential impacts on 
nature conservation and cultural heritage from resource recovery on former mineral extraction sites in England and Wales. Journal of Environmental Planning and Management, 62(7): 1227-1248.

Sinthumule, N. I., Ratshivhadelo, T., Nelwamondo, T. (2020). Stakeholder perspectives on land-use conflicts in the South African section of the Greater Mapungubwe Transfrontier Conservation Area. Journal of Land Use Science, 15(1): 114.

Steelman, T. A., Carmin, J. (1998). Common property, collective interests, and community opposition to locally unwanted land uses. Society and Natural Resources, 11(5): 485-504.

Sudoniene, V., Atkoceviciene, V. (2013). Land resources planning and management, Rural Development $6^{\text {th }}$ international scientific conference, 28-29 November 2013, Aleksandras Stulginskis University, 6(3): 456-461.

TMAF (2018). Republic of Turkey Ministry of Agriculture and Forestry, National Land Cover (CORINE) 2012. http://veri.tarimorman.gov.tr/layers/geonode:CLC2012 (Accessed Date: 8 December 2019).

Treworgy, C. G., Hindman, C. A. (1991). The Proximity of Underground Mines to Residential and Other Built-up Areas in Illinois. Environmental Geology, 138.

UMREK (2020). Current Situation in Turkey regarding Resource and Reserve Calculation, National Resources and Reserves Reporting Committee. http://www.umrek.com.tr/eng/index.php?id=current-state (Accessed
Date: 30 January 2020).

Ustaoglu, E., Aydınoglu, A.C. (2019). Regional variations of land-use development and land-use/cover change dynamics: A case study of Turkey. Remote Sensing, 11(7): 885; https://doi.org/10.3390/rs11070885.

van der Plank, S., Walsh, B., Behrens, P. (2016). The expected impacts of mining: Stakeholder perceptions of a proposed mineral sands mine in rural Australia. Resources Policy, 48: 129-136.

Walker, G., Mitchell, G., Fairburn, J., Smith, G. (2005). Industrial pollution and social deprivation: Evidence and complexity in evaluating and responding to environmental inequality. Local Environment, 10(4): 361-377.

Yılmaz Genç, S., Behradfar, A., Castanho, R.A., Kırıkkaleli, D., Gómez, J.M.N., Loures, L. (2021). Land use changes in Turkish territories: patterns, directions and socioeconomic impacts on territorial management. Current World Environment, 16(1): 1-18.

Zhang, T., Liu, R., Zheng, Z., \& Chi, Y. (2011). Mine environmental monitoring and evaluation using RS\&GIS in Chongqing, ICSDM 2011 - Proceedings 2011 IEEE International conference on spatial data mining and geographical knowledge services, 471-475.

Zou, H. (2019). Study on soil ecological environment restoration strategy of abandoned mining area. Arabian Journal of Geosciences 12 (23): 717. https://doi.org/10.1007/s12517019-4873-3. 